\title{
Taxonomic justification of the pathogenic strongylid infecting the Arabian camel Camelus dromedarius as Haemonchus longistipes by morphological and molecular phylogeny
}

\author{
Saad Dajem ${ }^{1}$, Kareem Morsy ${ }^{1,2}$, \\ Mohammed Al-Kahtani ${ }^{1}$, Rewaida Abdel-Gaber ${ }^{2,3}$ \\ ${ }^{1}$ Biology Department, College of Science, King Khalid University, 61421 Abha, Saudi Arabia \\ ${ }^{2}$ Department of Zoology, Faculty of Science, Cairo University, 12613 Cairo, Egypt \\ ${ }^{3}$ Biology Department, College of Science, King Saud University, 11451 Riyadh, Saudi Arabia \\ kareemsaid156@yahoo.com
}

Received: October 8, $2018 \quad$ Accepted: March 1, 2019

\begin{abstract}
Introduction: There is still lack of morphological and phylogenetic information on the pathogenic nematode of the camel Haemonchus longistipes. In the present study, this parasite was isolated in Saudi Arabia and described. Material and Methods: The abomasa of two Arabian camels were collected from a slaughterhouse in Abha province and examined for nematode infection. Worms were described morphologically and morphometrically by electron microscopy. Multiple sequence alignment and the phylogenetic tree of the parasite were constructed from maximum likelihood analysis of its ITS-2 rDNA sequences. Results: These nematodes had a slender body terminating anteriorly at a conspicuous dorsal lancet. A pair of lateral cervical papillae distant from the anterior end was observed. The buccal aperture was hexagonal and surrounded by two amphids, six externo-labial papillae, and four cephalic papillae. Males terminated posteriorly at a bursa supported by spicules and lateral and dorsal rays. Females were linguiform and knobbed morphotypes with distinct ovijectors and a dorsal rim covering the anal pore. The taxonomy was confirmed by the morphology and number of the longitudinal cuticular ridges in a $43-46$ range. The sequence alignment and phylogeny revealed 92\% homology with H. longistipes (AJ577461.1), and the sequence was deposited into GenBank. Conclusion: The present study describes H. longistipes morphologically and molecularly which facilitates further discrimination of this species worldwide.
\end{abstract}

Keywords: camels, Haemonchus longistipes, morphology, taxonomy, phylogeny.

\section{Introduction}

The Arabian camel (dromedary) is regarded as the national animal of Saudi Arabia and also "the ship of the desert" (1) because it was used in the past as the only means of travelling before the raising of horses and development of vehicles. The camel populations in Saudi Arabia have suffered extreme losses over the past year with no obvious reasons that can be stated. Some theories mentioned that this severe loss may be related to viral or parasitic infections that can hinder reproduction and afflict other organs (11). Gastrointestinal nematodes infecting ruminants, especially camels and sheep, are considered the most dangerous parasitic organisms causing severe economic losses and population loss worldwide (9). As an instance among the nematodes, some appear to be specific to the dromedary such as Haemonchus longistipes, Nematodirus mauritanicus, or Nematodirella dromedarii, while other camel nematodes such as Trichostrongylus prololurus, T. vitrinus, Ostertagia mongolica, Marshallagia mentulata, N. spathiger, or Oesophagostomum venulosum may infect sheep and goats (3). It seems that camel infection with these parasites is due to grazing on common pastures with these other host species. 
Haemonchus spp. (order Strongylida), which is called the large stomach worm, is a pathogenic haematophagous nematode infecting the abomasum of ruminant hosts and causing significant economic losses worldwide (11). These parasites are gravely problematic in camel husbandry because they not only reduce the productivity and performance of camels but also predispose them to other infectious diseases (7). Four suborders were recorded under the order Strongylida (5): the hookworms (Ancylostoma tina), the strongyles (Strongylina), trichostrongyles (Trichostrongylina) in which the genus Haemonchus is included, and metastrongyles (Metastrongylina), also known as lungworms. The mouth shape, their surrounding papillae, and the caudal bursa are the characteristic morphological features distinguishing one of these suborders from the others. Adult worms of Haemonchus spp. are attached to abomasal mucosa because they are blood feeders, and the "barber's pole" coloration is the trademark of female worms. Male worms are much smaller and have a well-developed copulatory bursa which is supported by asymmetrical spicules as well as lateral and dorsal lobes. Heavy infections with these nematodes may bring severe complications due to their ability of piercing abomasa, causing bleeding which in most cases leads to the death of the host (2). The complications include blood loss, anaemia, low activity, paleness of mucous membranes, dry skin, hair loss, and unstable movements (2). Four Haemonchus spp. are found in domestic ruminants: H. contortus (27), H. longistipes (25), H. placei (25), and $H$. similis (30). H. longistipes mainly infects the one-humped dromedary, which is the main type of camel in Saudi Arabia. H. contortus infects goats and sheep, while $H$. similis and $H$. placei parasitise cattle.

The rDNA ITS-2 sequences are the most commonly used markers to discriminate among nematode species (21). This region has been a popular choice because of its variability and concerted evolution and has been widely applied in species identification within the genus Haemonchus (14) for the accurate identification crucial to effective control due to the anthelmintic resistance problem in this nematode. El Bihari and Kawasmeh (8) and Hussein and Hussein (13) are the only available studies carried out on the prevalence of $H$. longistipes in camels inhabiting Saudi Arabia, and these research works have incomplete descriptions. Since there are few documented studies on the genetic variations among isolates of $H$. longistipes worldwide, the present study seeks to contribute a full description of the cameline haemonchosis caused by $H$. longistipes in Saudi Arabia based on morphological characterisation by light and scanning electron microscopy (SEM). Also, the study aims to validate the genetic variations in the ITS-2 region of the nematode DNA.

\section{Material and Methods}

Sample collection and parasitological study. The abomasa of two Arabian camels (Camelus dromedarius) were collected in May 2018 from the slaughterhouse at Abha province, Aseer region, Saudi Arabia, and transported to the Parasitology Laboratory of the Biology Department at the Faculty of Science of King Khalid University. The organs were placed individually in shallow plastic jars containing normal saline $(0.85 \%)$. Abomasum contents were poured into plastic jars, thoroughly mixed using a glass pipette, and sieved through a $25 \mu \mathrm{m}$ mesh. Various aliquots were then taken into Petri dishes and examined for the presence of nematode worms using a dissecting microscope. Worms were isolated and washed in normal saline solution to free them from mucus and then fixed in hot $70 \%$ ethyl alcohol. Some of the isolated worms were preserved in glycerine alcohol (glycerine 70\% alcohol, 1:3) and mounted in glycerine and glycerine jelly for light microscopy, while others were kept in the same fixative for molecular analysis. Photomicrographs showing the different structures of the recovered parasites were captured by an Olympus BX53F research photomicroscope supplied with builtin camera (Olympus, Japan). Worms were examined for cuticular ridges (number and arrangement) and vulvar morphology of females as described by Rose (26). The examination of male worms depended mainly on the shape and dimensions of the copulatory bursa which was separated from the remaining body and mounted for examination (15). They were drawn with the use of a camera lucida. For scanning electron microscopy (SEM), worms were fixed in buffered $4 \%$ glutaraldehyde in $0.1 \mathrm{M}$ sodium cacodylate followed by dehydration in an alcohol series $(50 \%, 60 \%, 70 \%, 80 \%$, $90 \%$, and $100 \%$ ). They were placed in a critical point drier (Bomer 900), coated with gold/palladium in a Technics Hummer V sputter coater (Anatech, USA), and then examined with a Jeol JSM7610F SEM (Jeol, Japan).

Molecular analyses. Adult specimens were homogenised in liquid nitrogen by a sterile mortar. After centrifugation of the homogenate, DNA was extracted from the pellets using DNA extraction kits (Qiagen, Germany) and then stored at $-20^{\circ} \mathrm{C}$ according to the provided protocols. The partial amplification of the ITS-2 of the worm's genome by PCR was carried out using the following primer sets: ITSF: 5'-ACGTCTGGTTCAGGGTTGT-3' and ITSR: 5'-TTAGTTTCTTTTCCTCCGCT-3' (21, 29). The PCR was performed in a total volume of $50 \mu \mathrm{L}$ containing $1 \times$ PCR buffer $(20 \mathrm{mM}$ Tris- $\mathrm{HCl}, \mathrm{pH} 8.4$, and $50 \mathrm{mM}$ of $\mathrm{KCl}$ ), $1.5 \mathrm{mM}$ of $\mathrm{MgCl}_{2}, 0.2 \mathrm{mM}$ of deoxynucleoside triphosphate mixture (dATP, dCTP, dGTP, and dTTP), 100 pmol of each primer, 2.5 units (U) of Thermus aquaticus (Taq) polymerase, $0.1 \mu \mathrm{g}$ of extracted parasite genomic DNA, and nuclease-free sterile double-distilled water. The mixture was 
then subjected to a precise thermal profile in a programmable thermocycler (Biometra, Germany) as follows: the denaturation step was set to $94^{\circ} \mathrm{C}$ for $120 \mathrm{~s}$, next came 35 cycles at $94^{\circ} \mathrm{C}$ for $40 \mathrm{~s}, 36^{\circ} \mathrm{C}$ for $40 \mathrm{~s}$, and $72^{\circ} \mathrm{C}$ for $60 \mathrm{~s}$, and the final extension step was $72^{\circ} \mathrm{C}$ for $600 \mathrm{~s}$. The amplified product (volume $10-15 \mu \mathrm{L})$ was confirmed by using agarose gel electrophoresis $(1.5 \%)$ as described by Mushonga et al. (24), and the DNA bands were stained with ethidium bromide $(0.5 \mu \mathrm{g} / \mathrm{ml})$ against a GeneRuler 100 bp Plus ready-to-use DNA ladder as a molecular weight marker (Fermentas, Canada). A DNA gel purification kit (Abgene, UK) was used to purify the PCR amplicons of the anticipated size from the gel. Sequencing was carried out with the same primer sets through the Big Dye Terminator v.3.1 Cycle Sequencing Kit (Applied Biosystems, USA) on a 3500 Genetic Analyzer automatic sequencer (Applied Biosystems). Sequences were aligned and compared with different species previously accessed in GenBank. Sequence identity for the recovered data was checked using the Basic Local Alignment Search Tool (BLAST) (www.ncbi.nih. gov/BLAST/). The sequence trimming for the congeneric species recovered was carried out by Bioedit v 7.2.5 (www.mbio.ncsu.edu/BioEdit/bioedit. html), sequence alignment was done by CLUSTAL W v2 (www.ebi.ac.uk/Tools/msa/clustalw2), and a phylogenetic tree was constructed using the MEGA 6 programme (www.megasoftware.net/archived_version_ active_download) based on maximum likelihood analysis. Ascaris suum (AF051702.1) was employed as an out-group. The data obtained from ITS-2 nucleotide sequencing were deposited in GenBank under accession number MH915579.

\section{Results}

In general, the recovered worms were yellowish, slender, tapered towards the anterior end in males and towards both ends in females (Fig. 1). The parasite was described by light microscopy (Figs. 2-17) as well as scanning electron microscopy (Figs 18-27). The buccal cavity had no buccal capsule; instead, they were endowed with a conspicuous dorsal lancet, the feeding apparatus that enables the worm to suck blood after piercing the abomasal (stomach) mucosa. The anterior ends of both sexes showed a pair of lateral wedgeshaped cervical papillae situated at a distance of $422-$ $467(444 \pm 5.0) \mu \mathrm{m}$ from the anterior end. In apical view, the buccal aperture was a hexagonal ring with two small amphids, six externo-labial papillae, and four cephalic papillae. Also, the presence of four crescentshaped cephalic plates, situated behind the median externo-labial papillae was documented. The body was covered by longitudinal cuticular ridges in addition to the transverse striations.

Female (based on 10 specimens). The knobbed and linguiform vulvar morphotypes were isolated from the same host with the latter encountered more predominantly. For the linguiform type, the body was 15.4-22.8 (19.2 \pm 3.0$) \mathrm{mm}$ long and the oesophagus, was $1.32-1.65(1.44 \pm 0.2) \mathrm{mm}$ long, constituting $7.2 \%-9.5 \%$ of the body length. The vagina was thickwalled and directed forwards parallel to the body and measured 90-130 $(110 \pm 4.0) \mu \mathrm{m}$. The vulvar opening was located at the anterior limit of the last third of the female's body at a distance of 530-640 (560 \pm 4.0$) \mu \mathrm{m}$ from the posterior end. The linguiform process was about 390-460 $(420 \pm 4.0) \mu \mathrm{m}$ long and was situated above the vulvar opening without cuticular inflation. The ovijector was well developed and consisted of distinct parts: anterior vestibule, anterior and posterior sphincters, and anterior and posterior infundibula. For the knobbed type, the length was 13.1-19.6 (17.5 $\pm 3.0) \mathrm{mm}$, and the oesophagus was $1.25-1.46(1.32$ $\pm 0.2) \mathrm{mm}$ long. The knobbed process was 117-134 $(123 \pm 3) \mu \mathrm{m}$ with a thick-walled vagina directed forwards obliquely to the body. In general for both morphs, the tail was spineless and the anal pore had a simple dorsal rim and muscular elements. Eggs in the uterus were 70-95 (85 \pm 4$) \mu \mathrm{m}$ long and 60-72 (60 $\pm 4) \mu \mathrm{m}$ wide.

Male (based on 10 specimens). The body was 12.7-18.6 (13.9 \pm 2.0$) \mathrm{mm}$ long, and the oesophagus was $1.10-1.33(1.15 \pm 0.2) \mathrm{mm}$ long, constituting $6.3 \%-10.0 \%(8.4 \%)$ of the body length. The caudal bursa had an ornate ventral surface composed mainly of two large lateral lobes and a reduced dorsal lobe. Lateral lobes were supported by long slender rays. Rays 2 and 3 had a very long, common stem, curved ventrally with extremities separated from each other. Ray 4 was straight, with extremities almost equidistant from those of rays 3 and 5. Rays 5 and 6 were parallel with extremities curved dorsally. Ray 8 was straight and thin. A small asymmetrical dorsal lobe with a dorsal ray (Y-shaped) was observed. The dorsal ray was stout and divided into two branches, each branch divided again into two parts (rays 9 and 10). Spicules were long with a length of 350-463 $(378 \pm 4.0) \mu \mathrm{m}$, and their tips were asymmetric, each provided with a small barb. No extra barbs were observed.

Synlophe. The cuticular ridge system extended from below the cephalic expansion and terminated in the posterior part of the body in both sexes at the prebursal or prevulval region. It was composed of definable lateral and dorsoventral ridges over the anterior $50 \%$ of the body and consisted of 40-46 ridges as a maximum. The cross section through the midoesophagus above the level of cervical papillae showed 6 ridges in each lateral field and 9 ridges in ventral and dorsal fields, only 30 ridges were present. The cross section through the intestine below the cervical ridge showed a mean of 40 ridges usually present in this region, including nine ridges in each lateral field and 11 ridges in the dorsal and ventral fields. No ridges were observed at the level of the vulvar region in the female. 

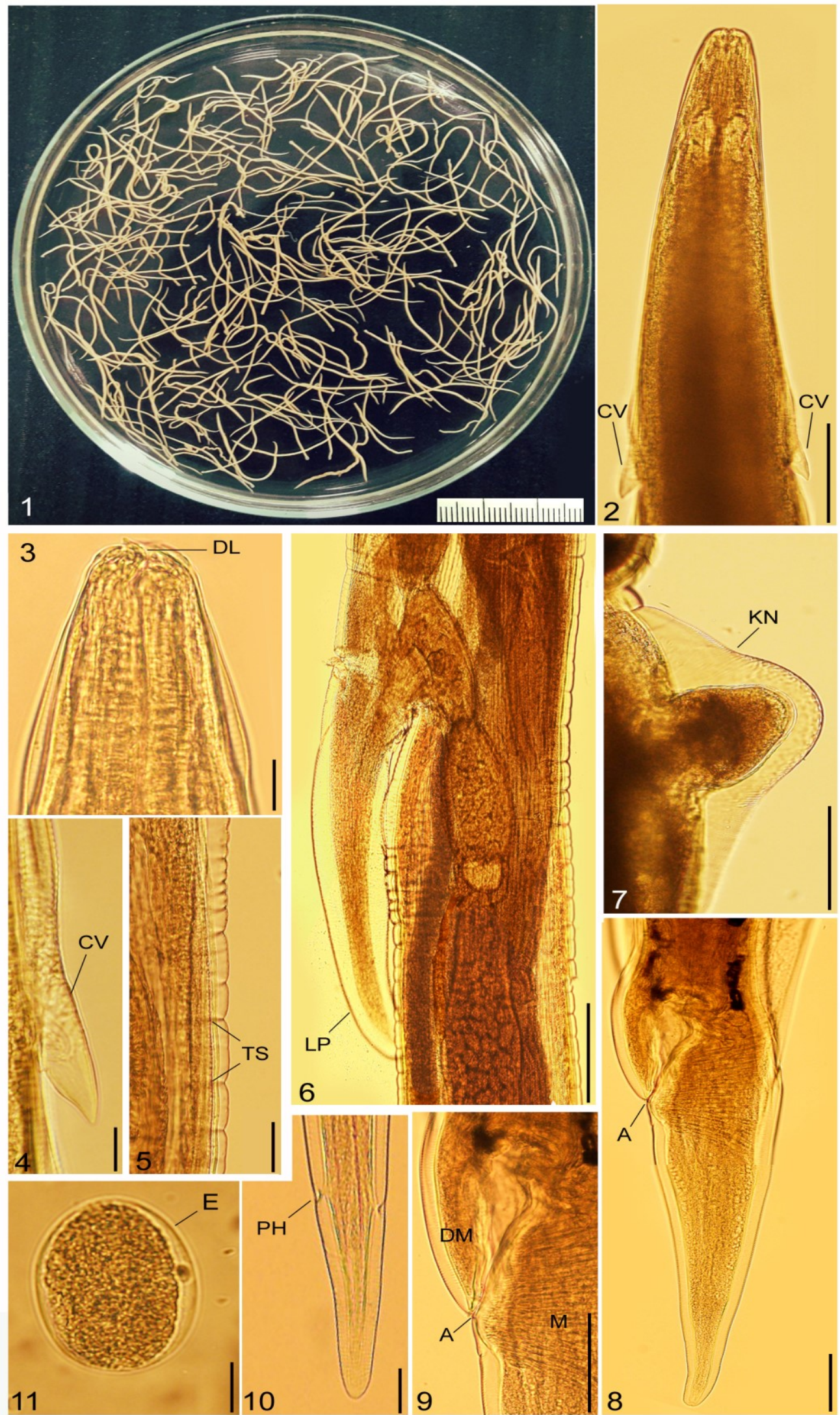

Figs 1-11. Haemonchus longistipes; 1 - photograph of whole worms (males and females) isolated from the intestine of the Arabian camel. 2-11 - photomicrographs showing 2,3 - the anterior part with two cervical papillae (CV) and a dorsal lancet (DL), scale bars $-100 \mu \mathrm{m}$ and $25 \mu \mathrm{m} .4$ - cervical papillae (CV), scale bar $-10 \mu \mathrm{m}$. 5 - transverse cuticle striations (TS), scale bar $-10 \mu \mathrm{m} .6$ - linguiform vulvar female with linguiform process (LP) and ovijector, scale bar - $100 \mu \mathrm{m} .7$ - knobbed vulvar type with knob $(\mathrm{KN})$, scale bar - 50 $\mu \mathrm{m} .8,9$ - the posterior region of female; A anus; covered by dorsal rim (DM), M muscles, scale bars $-100 \mu \mathrm{m}, 50 \mu \mathrm{m}$. 10 - phasmids $(\mathrm{PH})$, scale bar $-25 \mu \mathrm{m} .11$ - egg (E), scale bar $-25 \mu \mathrm{m}$ 
Six to ten ridges were distributed at the anterior end in the two lateral fields, the distribution of these ridges at the level of cervical papillae was a pair of lateral ridges separated by sublateral ridge 1, a pair of border ridges which terminated before the cephalic region, and four sublateral ridges were observed between the sublateral and border ridges. The second sublateral ridge terminated in the anterior part of the cervical papillae. The third sublateral ridge started at the level of the second sublateral ridge near the middle of the oesophagus and below the cervical papillae. The anterior origin of the first subventral and subdorsal ridges was the anterior half of the oesophageal region which was interrupted by the excretory pore, while the anterior origin of second subventral and subdorsal ridges were at or near to the oesophageal-intestinal junction. Subventral ridge 3 began bilaterally parallel to subventral ridge 2. Also, it was observed that lateral and sublateral ridges were taller and thicker than dorsals and ventrals. There were interruptions observed in the ridges of pairs 2 and 8 at the level of the excretory pore. Line diagrams show the different morphological diagnostic characteristics of H. longistipes in Fig. $28 \mathrm{a}-\mathrm{h}$.

Molecular study. Sequence analysis of the PCR amplicons indicated that the DNA fragments encoding the ITS-2 gene yielded 454 bp aligned with 22 nematode species belonging to the Stronglidae family retrieved from GenBank (Fig. 29). The relationship between the aligned sequences was calculated by the construction of a phylogenetic tree (Fig. 30) where the genetic distance between the aligned sequences is proportional to the horizontal line length. Two strongly supported clades were constructed in the phylogenetic tree: clade A and clade B (divided into subclades i, ii, and iii). The percentage of nucleotide identity between the Haemonchus sequences isolates and those of other ITS-2 relatives in GenBank ranged from $80 \%$ to $92 \%$, with a divergence ranging from 0.2 to 1.3 . Clade $\mathrm{B}$, to which different species of Haemonchus spp. belonged, showed $80 \%-92 \%$ identity indicating how closely they were related to the present sequences. Haemonchus spp. within clade Bi (H. placei and H. similis) use cattle as their main host, while those of clade Biii (H. contortus) mainly prefer sheep as their host animals. Sequences of the present parasite were identical with a $92 \%$ identity to $H$. longistipes sequences (accession no. AJ577461.1). These species were constructed as clade Bii in the tree representing Haemonchus spp. recorded in camels. The recovered sequences were deposited in GenBank under accession number MH 915579.

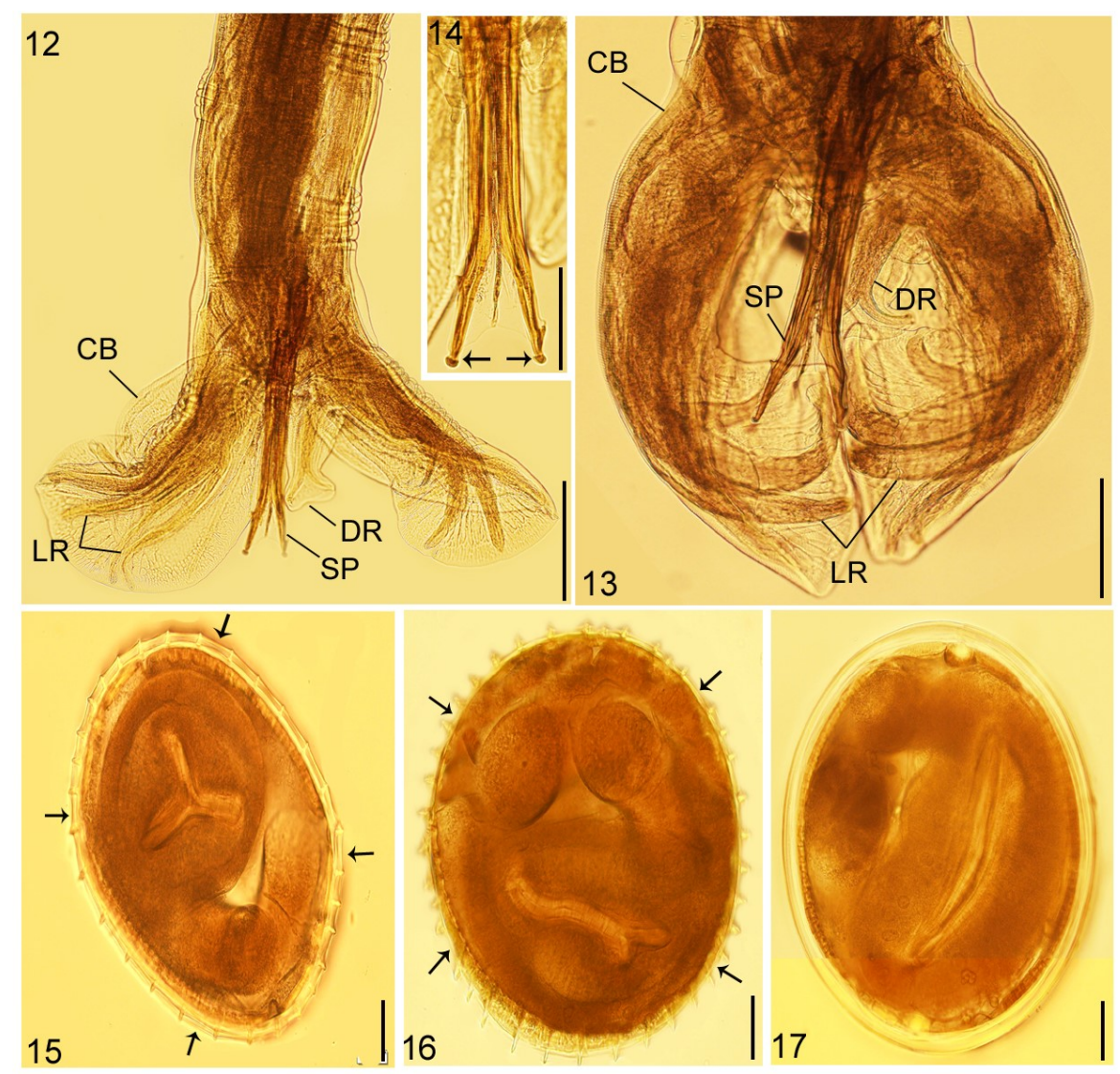

Figs 12-17. H. longistipes, photomicrographs showing: 12, 13 - copulatory bursa (CB) of male, extended and closed types respectively, with asymmetrical spicules (SP), lateral (LR), and dorsal rays (DR), scale bars $-150 \mu \mathrm{m}$ and $100 \mu \mathrm{m} .14$ - spicules (SP), asymmetrical with two small barbs at their tips (arrows), scale bar - 25 $\mu \mathrm{m}$. 14-17 - number and arrangement of synlophe, scale bars $-50 \mu \mathrm{m}$ : 15 - section through the mid-oesophagus above the level of cervical papillae including six ridges in each lateral field and nine ridges in ventral and dorsal fields; 16 - section at intestinal region below the cervical ridge showing 40 ridges, including 9 ridges in each lateral field, 11 ridges in the dorsal and ventral fields; 17 - section at the postvulvar region with no ridges 


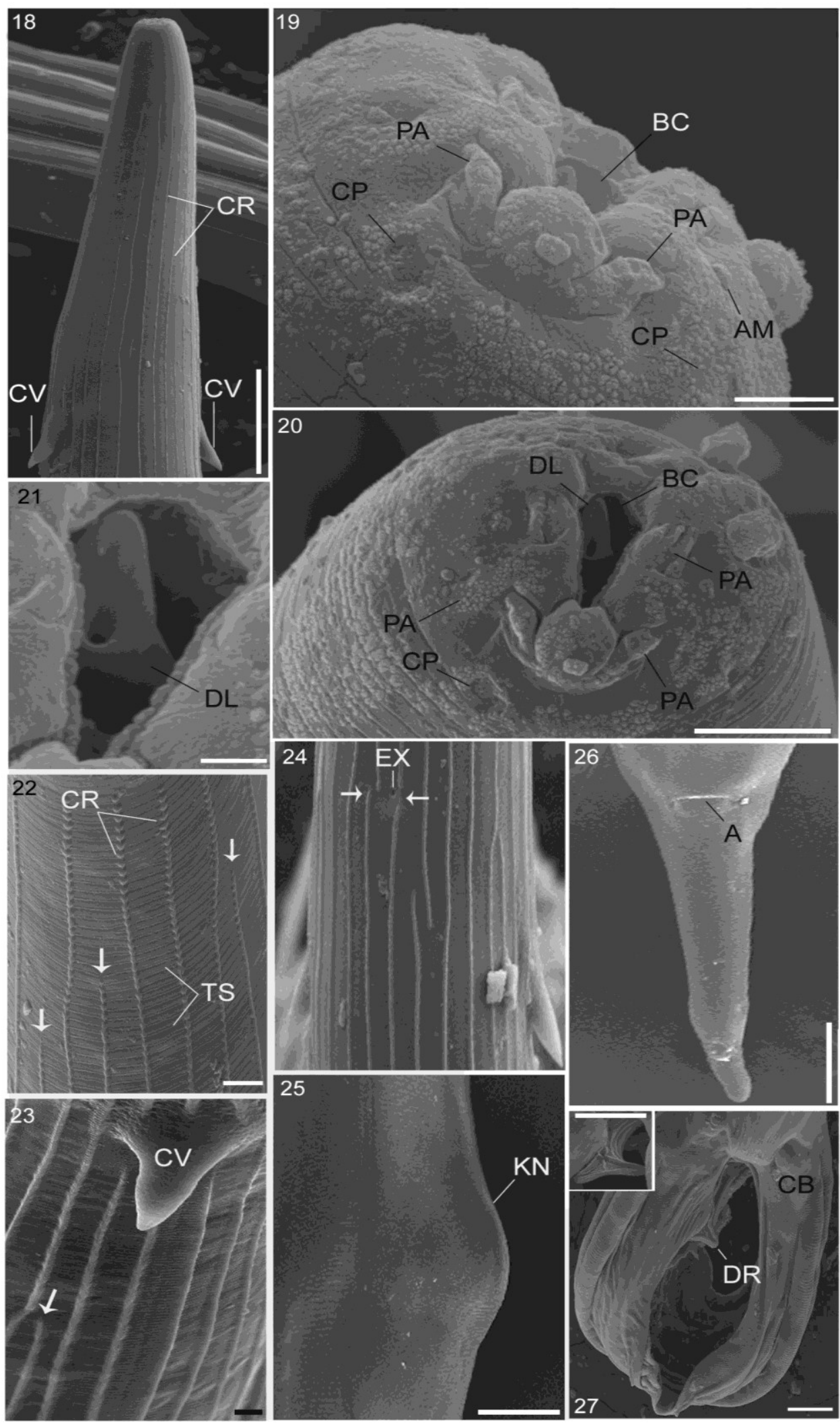

Figs 18-27. H. longistipes, scanning electron micrographs showing: 18 - anterior part with two lateral cervical papillae (CV) and longitudinal cuticular ridges or synlophe (CR), scale bar - $100 \mu \mathrm{m} .19,20$ - top views with extero-lateral papillae (PA), prominent dorsal lancet (DL) which is the blood feeding organelle, amphids (AM), and cephalic papillae (CP) surrounding buccal cavity (BC), scale bars $-5 \mu \mathrm{m}$ and $10 \mu \mathrm{m} .21$ - dorsal lancet (DL), scale bar $-2 \mu \mathrm{m} .22$ - anterior part below cephalic end with transverse cuticle striations (TS), the longitudinal cuticular ridges (CR) terminated at different levels (arrows), scale bar - $10 \mu \mathrm{m} .23$ - cervical region with cervical papillae (CV) and sublateral ridge (arrow) at high magnification, scale bar $-10 \mu \mathrm{m} .24-$ mid body, there are interruptions (arrows) in the cuticular ridges at the level of the excretory pore (EX), scale bar - $100 \mu \mathrm{m} .25$ - knobbed valvar form of female worms, $\mathrm{KN}$ - knob, scale bar - $100 \mu \mathrm{m} .26$ - posterior part of female, A - anus, scale bar - $100 \mu \mathrm{m} .27$ - copulatory bursa (CB) of male, scale bar - $100 \mu \mathrm{m}$; inset - dorsal ray (DR) at high magnification, scale bar $-100 \mu \mathrm{m}$ 

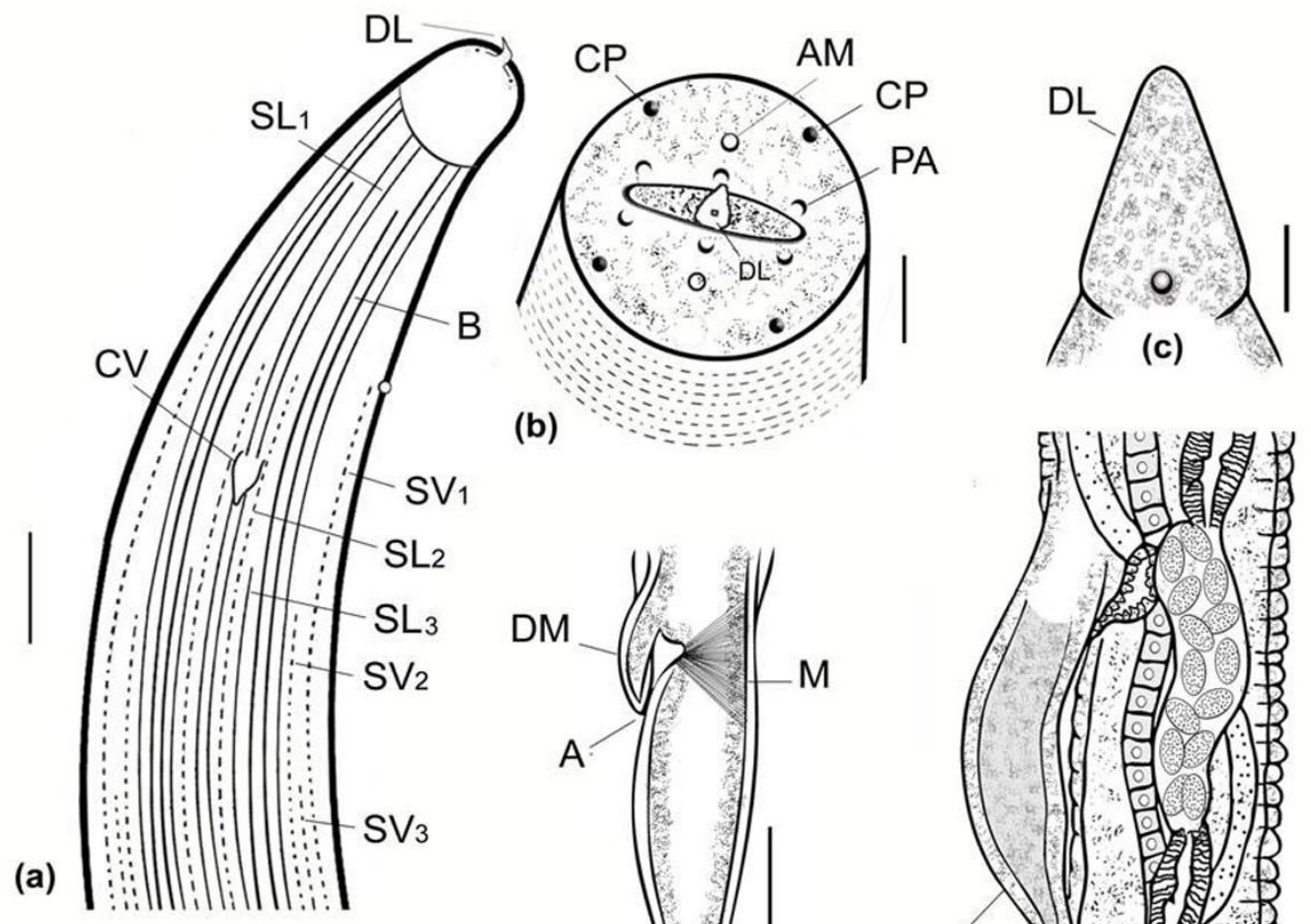

(b)
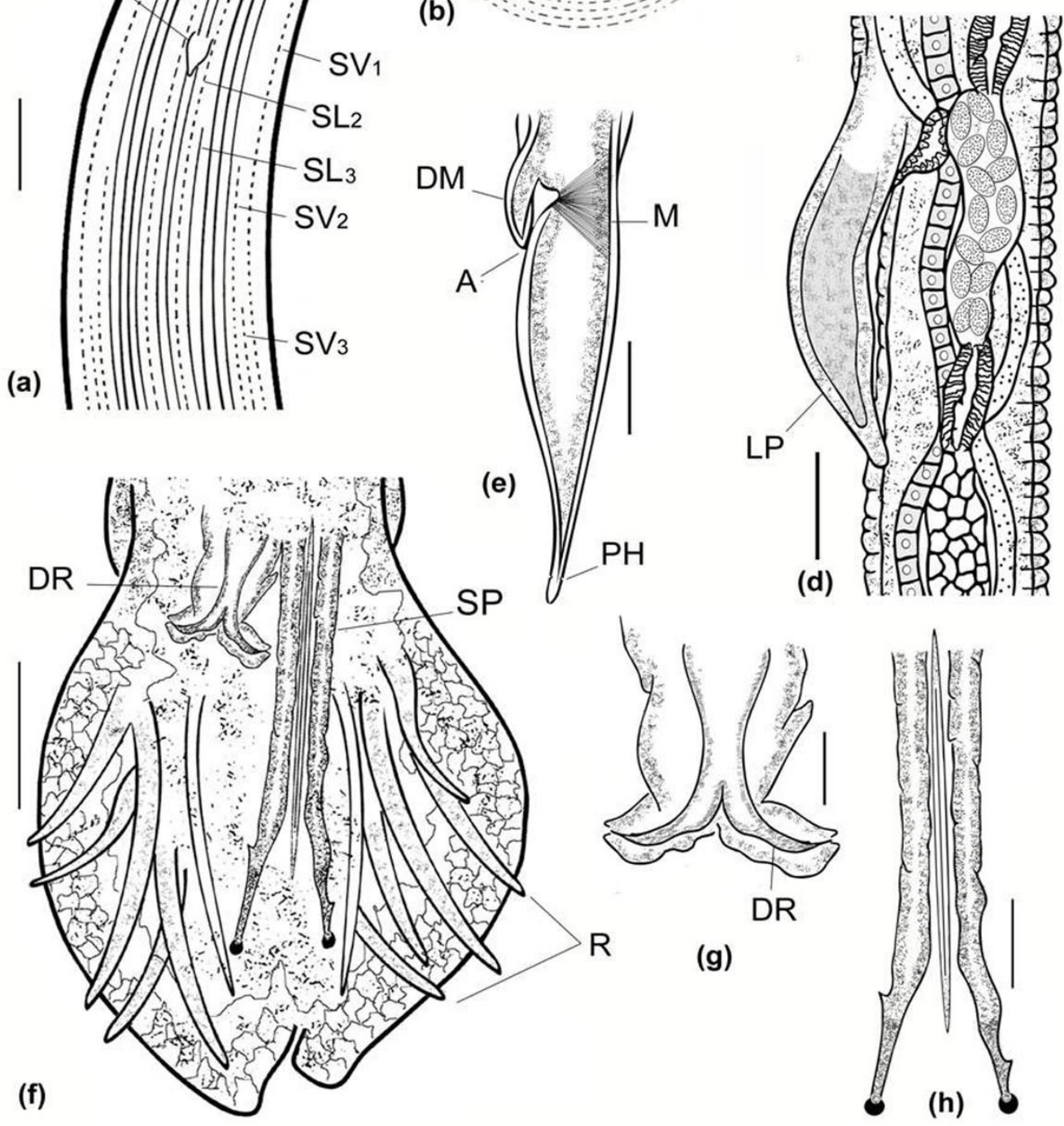

(d)

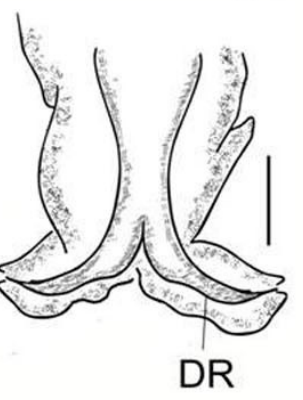

(g)

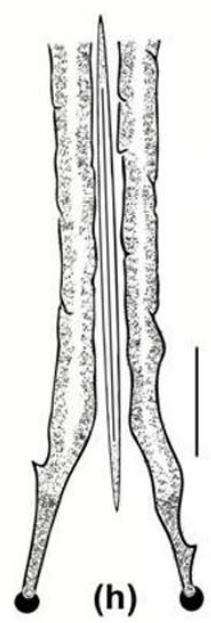

Fig. 28 (a-h). Line diagrams of H. longistipes: (a) Anterior extremity showing synlophe, lateral view, a pair of lateral ridges flanked by sublateral ridge 1 (SL1), a pair of border ridges (B) not extending all the way to the cephalic expansion, and four additional sublateral ridges SL2 and SL3 between SL1 and the border ridges (B). The anterior origin of the first subventral (SV1) and subdorsal ridges is the anterior half of the oesophageal region which is interrupted by the excretory pore. The second and third subventral ridges (SV2 and SV3) begin bilaterally parallel to SV1 terminating below the level of the cervical ridge $(\mathrm{CV})$, scale bar $-100 \mu \mathrm{m}$. (b) Top view showing the dorsal lancet (DL), six extero-labial papillae (PA), two amphids (AM), and the four cephalic papillae (CP), scale bar - $10 \mu \mathrm{m}$. (c) DL, scale bar - $1 \mu \mathrm{m}$. (d) Vulvar region of female, linguiform type with a process (LP) and ovijector, scale bar $-100 \mu \mathrm{m}$. (e) Posterior part of female showing the anal opening (A) covered by a dorsal rim (DR), M - muscles, PH - phasmids, scale bar - $100 \mu \mathrm{m}$. (f) Copulatory bursa of male, SP - spicules, LR - lateral rays, DR - dorsal ray, scale bar - $100 \mu \mathrm{m}$. (g) DR - dorsal ray, scale bar $-25 \mu \mathrm{m}$. (h) Asymmetrical spicules (SP) with two barbs at their tips, scale bar $-50 \mu \mathrm{m}$ 

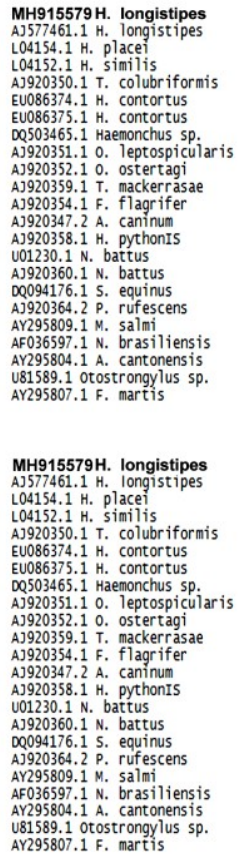
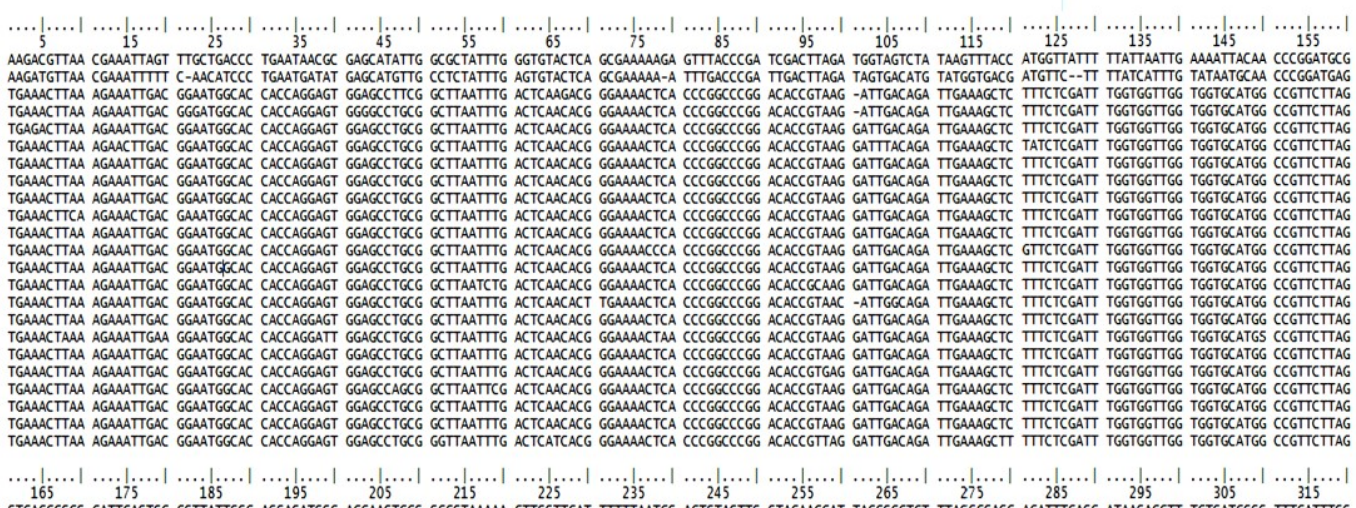

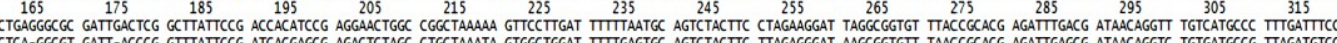

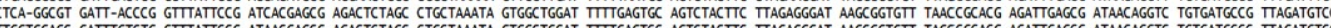

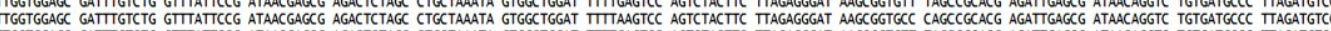

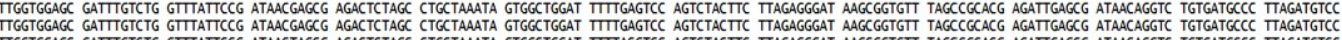

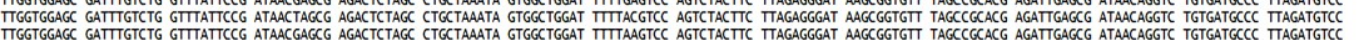

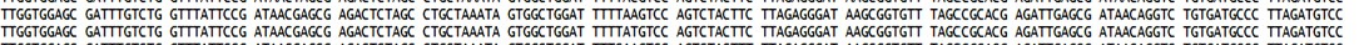

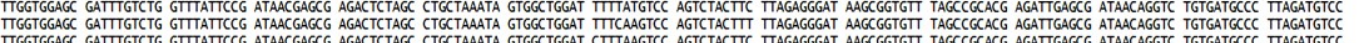

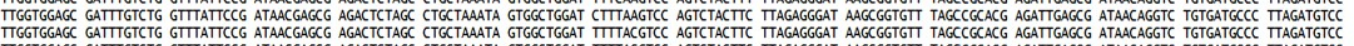

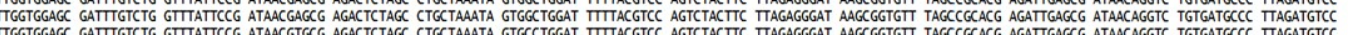
TGGTGGAGC GATTTGTCTG GTTATTCCG ATAACGAGGG AGACTCTAGC CTGCTAAAAT GCCTGGATT TACGTCCAG TCTACTTGG AGAGGGATAA GCGGTGITIA GCCGCAGGAG ATTGAGGGT AACGGGCTG TGATSCCCCT AGATGTCGGG

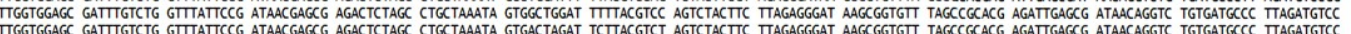

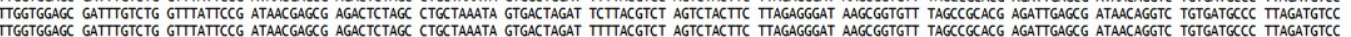

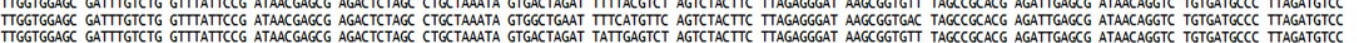

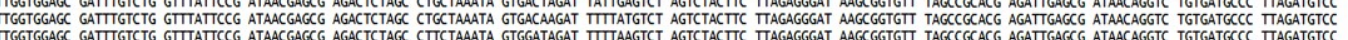

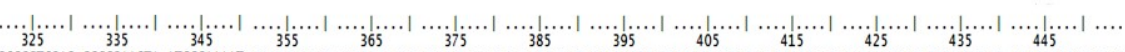

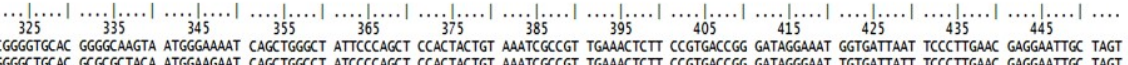$$
\text { GGGGCTGCAC GCGCCCCTACA ATGGAGGAAT CAGCTGGCCT ATCCATTGCC GAAAGGCAT GGTAAACCGT TGAAACTCT CCGGGGCCGG GATAGGGAAT TGTAATATT TCCCTTGAAC GAGGAATTCC TAGT }
$$$$
\text { GGGGCTGCAC GGGCGTTACA ATGGAGGAAT CAGCTGGCCT ATCCATTGCC GAAAGCCATT GGTAAACCGT TGAAACTCTT CCGTGACCGG GATAGGGAAT TGTAATTATT TCCCCTGGAC GAGGATTCC TAGT }
$$

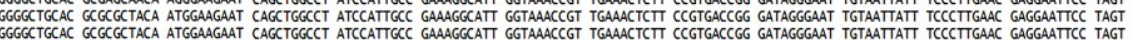

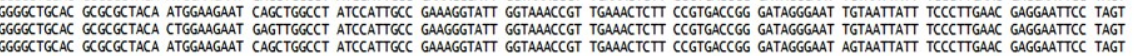

Fig. 29. Multiple sequence alignment of the partial DNA ITS-2 region derived from the comparative sequence analysis of H. longistipes isolated from slaughtered camels and previously reported haemonchinae deposited in GenBank

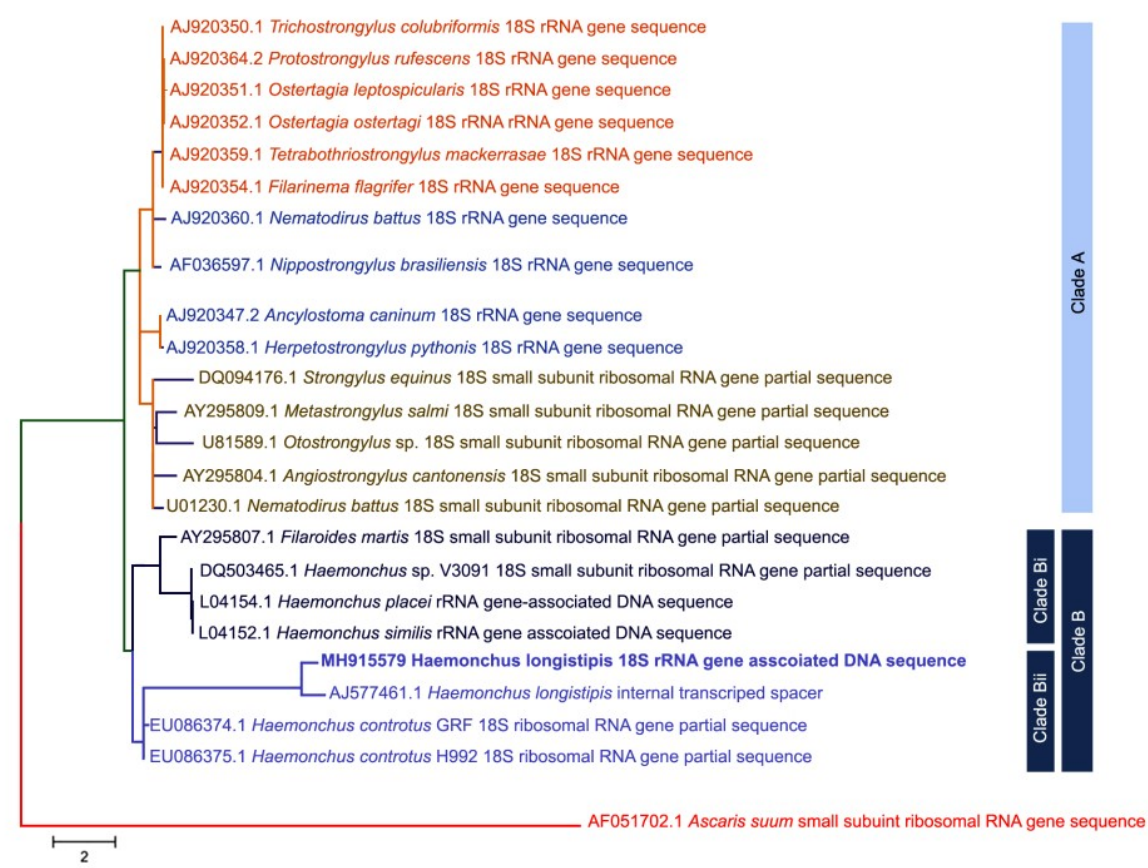

Fig. 30. Phylogenetic tree constructed by maximum likelihood method. The analysis involved 23 nucleotide sequences. All positions containing gaps and missing data were eliminated. There were a total of 454 positions in the final dataset. Evolutionary analyses were conducted in MEGA7 
Table 1. General reference scheme including morphological attributes among the crown genera of haemonchinae according to Lichtenfels and Pilitt (20)

\begin{tabular}{|c|c|c|c|c|c|c|c|c|}
\hline \multicolumn{2}{|c|}{ Parameters } & Species & H. bedfordi & H. contortus & H. dinniki & H. horaki & H. krugeri & H. lawrencei \\
\hline \multicolumn{3}{|c|}{ Body length } & 10 or less & 15 & 15 & 20 & 10 or less & 10 or less \\
\hline \multicolumn{3}{|c|}{ No. ridges } & 34 & 30 & 26 & 26 & 30 & 26 \\
\hline \multirow{2}{*}{\multicolumn{3}{|c|}{ 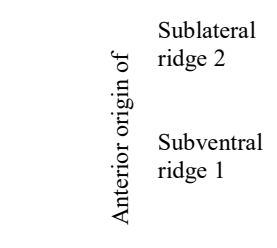 }} & $\begin{array}{l}\text { Near the level of } \\
\text { cervical papillae }\end{array}$ & $\begin{array}{l}\text { Near the level } \\
\text { of cervical } \\
\text { papillae }\end{array}$ & Absent & Absent & $\begin{array}{l}\text { Near the level of } \\
\text { cervical papillae }\end{array}$ & Absent \\
\hline & & & $\begin{array}{l}\text { Posterior half of } \\
\text { oesophageal } \\
\text { region, lateral to } 3 \\
\text { dorsal or ventral } \\
\text { ridges }\end{array}$ & Absent & Absent & Absent & Absent & Absent \\
\hline \multirow{5}{*}{ 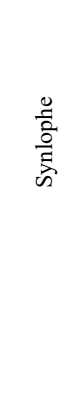 } & \multicolumn{2}{|c|}{ Thickness } & $\begin{array}{l}\text { Lateral and sub- } \\
\text { lateral ridges } \\
\text { taller and thicker } \\
\text { than dorsals and } \\
\text { ventrals }\end{array}$ & $\begin{array}{l}\text { Lateral and } \\
\text { sub-lateral } \\
\text { ridges taller } \\
\text { and thicker } \\
\text { than dorsals } \\
\text { and ventrals }\end{array}$ & $\begin{array}{l}\text { Lateral and sub-lateral } \\
\text { ridges taller and thicker } \\
\text { than dorsals and } \\
\text { ventrals }\end{array}$ & $\begin{array}{l}\text { All ridges nearly } \\
\text { equal in thickness } \\
\text { and height }\end{array}$ & $\begin{array}{l}\text { Lateral and sublateral } \\
\text { ridges taller and } \\
\text { thicker than dorsals } \\
\text { and ventrals }\end{array}$ & - \\
\hline & \multicolumn{2}{|c|}{ Shaft thickness } & Thick & Thin & Thin & Thin & Thin & Thick \\
\hline & \multicolumn{2}{|c|}{ Shaft shape } & $\begin{array}{l}\text { With median } \\
\text { bulge }\end{array}$ & $\begin{array}{l}\text { With median } \\
\text { bulge }\end{array}$ & With median bulge & Uniform thickness & Uniform thickness & $\begin{array}{l}\text { Uniform } \\
\text { thickness }\end{array}$ \\
\hline & \multicolumn{2}{|c|}{$\begin{array}{l}\% \text { dorsal ray } \\
\text { bifurcated } \\
\% \text { dorsal ray }\end{array}$} & $40 \%-50 \%$ & $40 \%-50 \%$ & $40 \%-50 \%$ & $40 \%-50 \%$ & $25 \%-33 \%$ & $25 \%-33 \%$ \\
\hline & \multicolumn{2}{|c|}{$\begin{array}{l}\text { branches } \\
\text { bifurcated }\end{array}$} & $20 \%$ or less & $20 \%$ or less & $40 \%-50 \%$ & $20 \%$ or less & $40 \%-50 \%$ & $40 \%-50 \%$ \\
\hline 苋 & \multicolumn{2}{|c|}{$\begin{array}{l}\text { Relative size of } \\
\text { ventral and } \\
\text { lateral rays }\end{array}$} & $\begin{array}{l}\text { Ventral and lateral } \\
\text { rays nearly equal }\end{array}$ & $\begin{array}{l}\text { Ventral and } \\
\text { lateral rays } \\
\text { nearly equal }\end{array}$ & $\begin{array}{l}\text { Ventral and lateral rays } \\
\text { nearly equal }\end{array}$ & $\begin{array}{l}\text { Ventral and lateral } \\
\text { rays nearly equal }\end{array}$ & $\begin{array}{l}\text { Ventral and lateral } \\
\text { rays nearly equal }\end{array}$ & $\begin{array}{l}\text { Ventral rays } \\
\text { larger than } \\
\text { laterals }\end{array}$ \\
\hline$\ddot{\infty}$ & \multirow{2}{*}{\multicolumn{2}{|c|}{$\begin{array}{l}\text { Total length } \\
\text { Symmetry } \\
\text { Barbs in relation } \\
\text { to distal tips }\end{array}$}} & $\begin{array}{l}400-450 \\
\text { asymmetric }\end{array}$ & $\begin{array}{l}400-450 \\
\text { Asymmetric }\end{array}$ & $\begin{array}{l}400 \\
\text { symmetric }\end{array}$ & $\begin{array}{l}500 \\
\text { Asymmetric }\end{array}$ & $\begin{array}{l}400 \\
\text { symmetric }\end{array}$ & $\begin{array}{l}400 \\
\text { symmetric }\end{array}$ \\
\hline 㲞 & & & Separate from tips & $\begin{array}{l}\text { Separate from } \\
\text { tips }\end{array}$ & Separate from tips & Separate from tips & Barb part of tips & $\begin{array}{l}\text { Separate from } \\
\text { tips }\end{array}$ \\
\hline$\frac{0}{\sum^{\pi}}$ & \multicolumn{2}{|c|}{ Extra barbs } & No extra barbs & No extra barbs & No extra barbs & No extra barbs & No extra barbs & $\begin{array}{l}\text { Barb on each } \\
\text { spicule tip }\end{array}$ \\
\hline & \multicolumn{2}{|c|}{ Shape } & $\begin{array}{l}\text { Short cone (ratio } \\
\text { of length to the } \\
\text { greatest width less } \\
\text { than 4) }\end{array}$ & $\begin{array}{l}\text { Elongate, } \\
\text { uneven } \\
\text { tapering (ratio } \\
\text { of length to the } \\
\text { greatest width } \\
4.5-6 \text { ) }\end{array}$ & $\begin{array}{l}\text { Elongate, uneven } \\
\text { tapering (ratio of length } \\
\text { to the greatest width } \\
4.5-6 \text { ) }\end{array}$ & $\begin{array}{l}\text { Elongate, uneven } \\
\text { tapering (ratio of } \\
\text { length to the greatest } \\
\text { width } 4.5-6 \text { ) }\end{array}$ & $\begin{array}{l}\text { Elongate, uneven } \\
\text { tapering (ratio of } \\
\text { length to the greatest } \\
\text { width } 4.5-6 \text { ) }\end{array}$ & $\begin{array}{l}\text { Short cone } \\
\text { (ratio of } \\
\text { length to the } \\
\text { greatest width } \\
\text { less than 4) }\end{array}$ \\
\hline$\overline{\widetilde{\sigma}}$ & \multicolumn{2}{|c|}{ Length } & Greater than $2 \%$ & $\begin{array}{l}\text { Greater than } \\
2 \%\end{array}$ & Greater than $2 \%$ & Greater than $2 \%$ & Greater than $2 \%$ & $\begin{array}{l}\text { Greater than } \\
2 \%\end{array}$ \\
\hline
\end{tabular}

\begin{tabular}{|c|c|c|c|c|c|c|c|c|}
\hline \multicolumn{2}{|c|}{ Parameters } & Species & H. longistipes & H. mitchelli & H. okapiae & H. placei & H. similis & H. vegliai \\
\hline \multicolumn{3}{|c|}{ Body length } & 20 & 15 & 15 & 15 & 10 or less & 15 \\
\hline \multicolumn{2}{|c|}{ No. ridges } & & 36 & 36 & 36 & 34 & 34 & 36 \\
\hline \multirow{4}{*}{$\begin{array}{l}\frac{0}{0} \\
\text { 言- } \\
\text { हn }\end{array}$} & \multirow{2}{*}{ 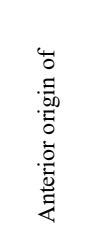 } & $\begin{array}{l}\text { Sublateral } \\
\text { ridge } 2\end{array}$ & $\begin{array}{l}\text { Substantially } \\
\text { anterior to } \\
\text { cervical papillae }\end{array}$ & $\begin{array}{l}\text { Near the level of } \\
\text { cervical papillae }\end{array}$ & $\begin{array}{l}\text { Near the level of } \\
\text { cervical papillae }\end{array}$ & $\begin{array}{l}\text { Near the level of } \\
\text { cervical papillae }\end{array}$ & $\begin{array}{l}\text { Near the level of } \\
\text { cervical papillae }\end{array}$ & $\begin{array}{l}\text { Near the level of } \\
\text { cervical papillae }\end{array}$ \\
\hline & & $\begin{array}{l}\text { Subventral } \\
\text { ridge } 1\end{array}$ & $\begin{array}{l}\text { Anterior half of } \\
\text { oesophageal } \\
\text { region, lateral to } 3 \\
\text { dorsal or ventral } \\
\text { ridges }\end{array}$ & $\begin{array}{l}\text { Anterior half of } \\
\text { oesophageal } \\
\text { region, lateral to } 3 \\
\text { dorsal or ventral } \\
\text { ridges }\end{array}$ & $\begin{array}{l}\text { Anterior half of } \\
\text { oesophageal } \\
\text { region, lateral to } 3 \\
\text { dorsal or ventral } \\
\text { ridges }\end{array}$ & $\begin{array}{l}\text { Anterior half of } \\
\text { oesophageal } \\
\text { region, lateral to } 3 \\
\text { dorsal or ventral } \\
\text { ridges }\end{array}$ & $\begin{array}{l}\text { Anterior half of } \\
\text { oesophageal } \\
\text { region, lateral to } 3 \\
\text { dorsal or ventral } \\
\text { ridges }\end{array}$ & $\begin{array}{l}\text { Anterior half of } \\
\text { oesophageal } \\
\text { region, lateral to } 3 \\
\text { dorsal or ventral } \\
\text { ridges }\end{array}$ \\
\hline & \multicolumn{2}{|c|}{ Thickness } & $\begin{array}{l}\text { Lateral and } \\
\text { sublateral ridges } \\
\text { taller and thicker } \\
\text { than dorsals and } \\
\text { ventrals }\end{array}$ & $\begin{array}{l}\text { Lateral and } \\
\text { sublateral ridges } \\
\text { taller and thicker } \\
\text { than dorsals and } \\
\text { ventrals }\end{array}$ & - & $\begin{array}{l}\text { Lateral and } \\
\text { sublateral ridges } \\
\text { taller and thicker } \\
\text { than dorsals and } \\
\text { ventrals }\end{array}$ & $\begin{array}{l}\text { Lateral and } \\
\text { sublateral ridges } \\
\text { taller and thicker } \\
\text { than dorsals and } \\
\text { ventrals }\end{array}$ & $\begin{array}{l}\text { Lateral and } \\
\text { sublateral ridges } \\
\text { taller and thicker } \\
\text { than dorsals and } \\
\text { ventrals }\end{array}$ \\
\hline & \multicolumn{2}{|c|}{ Shaft thickness } & Thin & Thick & Thick & Thin & Thin & Thick \\
\hline & \multicolumn{2}{|c|}{ Shaft shape } & $\begin{array}{l}\text { With median } \\
\text { bulge }\end{array}$ & Thickened at base & Uniform thickness & With median bulge & With median bulge & Thickened at base \\
\hline \multirow{4}{*}{ 萬 } & \multirow{2}{*}{\multicolumn{2}{|c|}{$\begin{array}{l}\% \text { dorsal ray bifurcated } \\
\% \text { dorsal ray branches } \\
\text { bifurcated }\end{array}$}} & $25 \%-33 \%$ & $25 \%-33 \%$ & $40 \%-50 \%$ & $40^{\wedge} \%-50 \%$ & $40 \%-50 \%$ & $25 \%-33 \%$ \\
\hline & & & $20 \%$ or less & $20 \%$ or less & $20 \%$ or less & $20 \%$ or less & $20 \%$ or less & $20 \%$ or less \\
\hline & \multicolumn{2}{|c|}{$\begin{array}{l}\text { Relative size of ventral } \\
\text { and lateral rays }\end{array}$} & $\begin{array}{l}\text { Ventral and lateral } \\
\text { rays nearly equal }\end{array}$ & $\begin{array}{l}\text { Ventral and lateral } \\
\text { rays nearly equal }\end{array}$ & $\begin{array}{l}\text { Ventral and lateral } \\
\text { rays nearly equal }\end{array}$ & $\begin{array}{l}\text { Ventral and lateral } \\
\text { rays nearly equal }\end{array}$ & $\begin{array}{l}\text { Ventral and lateral } \\
\text { rays nearly equal }\end{array}$ & $\begin{array}{l}\text { Ventral and lateral } \\
\text { rays nearly equal }\end{array}$ \\
\hline & \multicolumn{2}{|c|}{ Total length } & 500 & 500 & $400-450$ & $400-450$ & 400 & $400-450$ \\
\hline \multirow{4}{*}{ 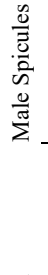 } & \multirow{2}{*}{\multicolumn{2}{|c|}{$\begin{array}{l}\text { Symmetry } \\
\text { Barbs in relation to } \\
\text { distal tips }\end{array}$}} & Asymmetric & Asymmetric & Asymmetric & Asymmetric & Asymmetric & Asymmetric \\
\hline & & & Separate from tips & Separate from tips & Separate from tips & Separate from tips & Separate from tips & Separate from tips \\
\hline & \multicolumn{2}{|c|}{ Extra barbs } & No extra barbs & $\begin{array}{l}1 \text { barb on right } \\
\text { spicule tip }\end{array}$ & $\begin{array}{l}1 \text { barb on right } \\
\text { spicule tip }\end{array}$ & No extra barbs & No extra barbs & $\begin{array}{l}1 \text { barb on right } \\
\text { spicule tip }\end{array}$ \\
\hline & \multicolumn{2}{|l|}{ Shape } & $\begin{array}{l}\text { Short cone (ratio } \\
\text { of length to the } \\
\text { greatest width less } \\
\text { than } 4 \text { ) }\end{array}$ & $\begin{array}{l}\text { Elongate, uneven } \\
\text { tapering (ration of } \\
\text { length to the } \\
\text { greatest width } \\
4.5-6 \text { ) }\end{array}$ & $\begin{array}{l}\text { Short cone (ratio } \\
\text { of length to the } \\
\text { greatest width less } \\
\text { than 4) }\end{array}$ & $\begin{array}{l}\text { Short cone (ratio } \\
\text { of length to the } \\
\text { greatest width less } \\
\text { than } 4 \text { ) }\end{array}$ & $\begin{array}{l}\text { Short cone (ratio of } \\
\text { length to the } \\
\text { greatest width less } \\
\text { than } 4 \text { ) }\end{array}$ & $\begin{array}{l}\text { Short cone (ratio of } \\
\text { length to the } \\
\text { greatest width less } \\
\text { than } 4 \text { ) }\end{array}$ \\
\hline Еี & \multicolumn{2}{|l|}{ Length } & Less than $2 \%$ & Less than $2 \%$ & Less than $2 \%$ & Greater than $2 \%$ & Less than $2 \%$ & Less than $2 \%$ \\
\hline
\end{tabular}




\section{Discussion}

Parasite control and management of camel husbandry represent a huge problem worldwide, especially in Saudi Arabia where camels become susceptible to viral and parasitic infections from pasture during feed intake (1). Haemonchus spp. is one of the major species that cause economic losses in ruminant livestock worldwide $(17,23)$. Haemonchus longistipes is a principal parasite of camels for which some morphological as well as molecular data are missing, both in general and with particular pertinence to Saudi Arabia (25). Prior to the present investigation no reports had been published since the studies of El Bihari and Kawasmeh (8) and Hussein and Hussein (13), which were only numerical records. Morphological details including the arrangement of the cuticular ridge system, rays and spicules of the male bursa, the terminal end of female tail and the shape of the anal pore represent the most helpful criteria to researchers for distinguishing the different species of Haemonchinae and Ostertagiinae (21). Lichtenfels and Pilitt (18) developed an important reference guide (Table 1) for haemonchinae based on the ridge systems. The guide is based on whole mount preparations of the examined worm or on transverse sections through the body at the oesophagealintestinal junction, then the number, arrangement, and the presence or absence of sublateral, subventral, and border ridges were observed. According to this key, it was observed that the nematodes isolated in the current study possessed most of the criteria characteristics for $H$. longistipes such as long females with a body length about $20 \mathrm{~mm}$, the number of ridges composing synlophe at the level of oesophagealintestinal junction 36 or more, cuticular ridges in males and females terminated in the anterior half of the body, posterior termination of sublateral and subventral ridges at or near the posterior end of synlophe, the anterior origin of the first subventral and subdorsal ridges at the anterior half of the oesophageal region, lateral and sublateral ridges taller and thicker than dorsals and ventrals, asymmetric male spicules with barbs present on each spicule tip, and an asymmetric dorsal ray of the bursa and the tail of adult females with a short cone. The diagnosis as well as generic and specific levels of haemonchine members depends mainly on the number and arrangement of ridge systems and their gradient (19). The importance of this system in taxonomic identification of nematodes was firstly studied by Skrjabin et al. (28) and Durette-Desset (6) through sections at the worm mid-body (4). The results of this study clearly show that characteristics of the synlophe can be used to identify Haemonchus spp. The uniformity of the characteristics of the synlophes of the present species of Haemonchus agrees with the results of earlier studies by Lichtenfels (16), Lichtenfels et al. (20), and Morsy et al. (22). All these studies showed that the synlophe morphology is uniform in character with little variation among populations from different regions of the world. The arrangement of cuticular ridges for the present parasite and interruptions of the cuticular ridges at the level of the excretory pore coincide with the key established by Lichtenfels and Pilitt (18) for H. longistipes.

The sequence alignment and phylogenetic tree showed that members of Trichostrongylina include the monophyletic Haemonchinae as a sister group to the Ostertagiinae (12). H. longistipes samples subjected to PCR expressed a $454 \mathrm{bp}$ fragment of the ITS-2, which is a stable conserved region among trichostrongyloid genomes. Haemonchus infections in domestic mammals can be distinguished from other trichostrongyloid parasites by the use of PCR techniques through the amplification of the helminth's ITS-2 DNA (10). The PCR products obtained in the present study were purified and sequenced for proper confirmation. Sequence alignment between the present parasites and those retrieved from Genank showed a high percentage of identity among Haemonchus spp., which is confirmed by the previous studies which stated that the aetiological agent isolated from cases of parasitic gastroenteritis in camels is $H$. longistipes. This was proved in the present study through the construction of the phylogenetic tree which is important for nematode taxonomy which aligns with many previous reports $(7,21)$. Comparative sequence analysis revealed $80 \%$ to $92 \%$ homology with Haemonchus sequences recovered from GenBank, and this agreed with different molecular studies by El-Bahy et al. (7) and Hussain et al. (14) who mentioned that there was a uniformity in the sequence characteristics between Haemonchus spp. where the level of variation in ITS2 species between sites was low. Since there is incompleteness in the studies regarding the morphological and molecular characteristics of $H$. longistipes infecting camels worldwide, the present study provided data of morphological and molecular characteristics of this species in the hope of facilitating its further discrimination from other haemonchinae.

Conflict of Interests Statement: The authors declare that there is no conflict of interests regarding the publication of this article.

Financial Disclosure Statement: This work was funded by the Deanship of Scientific Research at the King Khalid University through the General Research Project under grant number (G.R.P-403-39).

Animal Rights Statement: The authors declare that the experiments on animals were conducted in accordance with local Ethical Committee laws and 
regulations as regards care and use of laboratory animals.

Acknowledgment: The authors extend their appreciation to the Deanship of Scientific Research at King Khalid University for funding this work through the General Research Project under grant number G.R.P-403 -39.

\section{References}

1. Abdallah H.R., Faye B.: Typology of camel farming system in Saudi Arabia. Emir J Food Agric 2013, 25, 250-260.

2. Bahirathan M., Miller J.E., Barras S.R., Kearney M.T.: Susceptibility of Suffolk and Gulf Coast Native suckling lambs to naturally acquired strongylate nematode infections. Vet Parasitol 1996, 65, 259-260.

3. Banaja A.A., Ghandour A.M.: A review of parasites of camel (Camelus dromedarius) in Saudi Arabia. J King Abdulaziz Univ Sci 1994, 6, 75-86.

4. Durette-Desset M.C.: Keys to the genera of the superfamily Trichostrongyloidea. In: $\mathrm{CIH}$ keys to the nematode parasites of vertebrates, edited by Anderson R.C. and. Chabaud A.G. Commonwealth Agricultural Bureaux, Farnham Royal, U.K., 1983, pp. 1-86.

5. Durette-Desset M.C., Chabaud A.G.: Nomenclature des Strongylida au-dessus du groupe-famille. Ann Parasitol Hum Comp 1993, 68, 111-112.

6. Durette-Desset M.C.: Les systemes d'arêtes cuticulaires chez les Nématodes Héligmosomes: Etude de cinq espèces parasites de Rongeurs de la Maboke. Cahiers de la Maboke 1964, 2, 39-78.

7. El-Bahy M.M., El-Bahy N.M., Shalaby H.A.: Value of Haemonchus longistipes purified antigens in diagnosis of gastrointestinal nematodes infection in camels. Pak J Biol Sci 2007, 10, $1452-1458$.

8. El Bihari S., Kawasmeh Z.A.: Occurrence and seasonal variation of some gastrointestinal helminths of the dromedary, Camelus dromedarius, in Saudi Arabia. Proc Saudi Biol Soc 1980, 4, 297-304.

9. Fabiyi J.P.: Production losses and control of helminths in ruminants of tropical regions. Int J Parasitol 1987, 17, 435-442.

10. Gharamah A.A., SitiAzizah M.N., Rahman W.A.: Genetic variation of $H$. contortus (Trichostrongylidae) in sheep and goats from Malaysia and Yemen. Vet Parasitol 2012, 188, 268-276.

11. Habte A., Ibrahim N.: Prevalence of Haemonchus contortus infection in sheep slaughtered at Jimma town municipal abattoir, Ethiopia. Trop Anim Health Prod 2018, doi: 10.1007/s11250018-1637-0.

12. Hoberg E.P., Lichtenfels J.R.: Phylogenetic systematic analysis of the Trichostrongylidae (Nematoda) with an initial assessment of coevolution and biogeography. J Parasitol 1994, 80, 976-996.

13. Hussein S.H., Hussein M.F.: The prevalence and pathology of Haemonchus longistipes infection in Saudi Arabian camels (Camelus dromedarius). Proc Saudi Biol Soc 1985, 8, 247-257.

14. Hussain T., Periasamy K., Nadeem A., Babar M.E., Pichler R., Diallo A.: Sympatric species distribution, genetic diversity and population structure of Haemonchus isolates from domestic ruminants in Pakistan. Vet Parasitol 2014, 15, 206, 188-99.

15. Jacquiet P., Cabaret J., Cheikh D., Thiam E.: Identification of Haemonchus species in domestic ruminants based on morphometrics of spicules. Parasitol Res 1997, 83, 82-86.

16. Lichtenfels J.R.: Differences in cuticular ridges among Cooperia spp. of North American ruminants with an illustrated key to species. Proc Helminthol Soc Wash 1977, 44, 111-119.

17. Lichtenfels J.R., Pilitt P.A., Hoberg E.P.: New morphological characters for identifying individual specimens of Haemonchus spp. (Nematoda: Trichostrongyloidea) and a key to species in ruminants of North America. J Parasitol 1994, 80, 107-119.

18. Lichtenfels J.R., Pilitt P.A.: Synlophe patterns of the Haemonchinae of ruminants (Nematoda: Trichostrongyloidea). J Parasitol 2000, 86, 1093-1098.

19. Lichtenfels J.R., Patricia A.P., Lynda M.G., Eric P.H.: Redescriptions of Haemonchus mitchelli and Haemonchus okapiae (Nematoda: Trichostrongyloidea) and description of a unique synlophe for the Haemonchinae. J Parasitol 2002, 88, 947960 .

20. Lichtenfels J.R., Pilitt P.A., Le Jambre L.F.: Cuticular ridge patterns of Haemonchus contortus and Haemonchus placei (Nematoda: Trichostrongyloidea). Proc Helminthol Soc Wash 1986, 53, 94-101.

21. Meshgi B., Jalousian F., Masih Z.: Phylogenetic study of Haemonchus species from Iran based on morpho-molecular characterization. Iran J Parasitol 2015, 10, 189-96.

22. Morsy K., Bashtar A.R., Fol M., Yehia Y.: Haemonchus longistipes Railliet \& Henry, 1909 (Nematoda, Trichostrongylidae) from the Egyptian dromedary, Camelus dromedarius (Artiodactyla: Camelidae), first identification on the basis of light and ultrastructural data Parasitol Res 2014, 113, 4579-4585.

23. Moudgil A.D., Sharma A., Verma M.S., Kumar R., Dogra P.K., Moudgil P.: Gastrointestinal parasitic infections in Indian Gaddi (goat) breed bucks: clinical, hemato-biochemical, parasitological, and chemotherapeutic studies. J Parasit Dis 2017, 41, 1059-1065.

24. Mushonga B., Habumugisha D., Kandiwa E., Madzingira O., Samkange A., Segwagwe B.E., Jaja I.F.: Prevalence of Haemonchus contortus infections in sheep and goats in Nyagatare District, Rwanda. J Vet Med 2018, doi: 10.1155/2018/3602081.

25. Railliet H., Henry A.: Un nouveau selérostomien (Triodontophorus deminutus Nov Sp.) parasite de l'homme. CR Soc Biol 1905, 58, 509-571.

26. Rose J.H.: The vulval flap formula of Haemonchus contortus from sheep in South east England. Res Vet Sci 1966, 7, 480-483.

27. Rudolphi G.A.: Fortesetzing der Beobachtingen uber die Eingewel dewurmer. Arch Zool U Zoot 1802, 2, 23-25.

28. Skrjabin K.I., Shikhabalova N.P., Shul'ts R.S.: Trichostrongylids of animals and man. Osnovy Nematodologii III. Academy of Sciences, USSR, Moscow, USSR. Jerusalem 1954, pp. 704.

29. Stevenson L.A., Chilton N.B., Gasser R.B.: Differentiation of H. placei from H. contortus (Nematoda: Trichostrongylidae) by their second internal transcribed spacer (ribosomal DNA). Int J Parasitol 1999, 25, 483-488.

30. Travassos L.: Trichostrongylinae brazileiras. Haemonchus similis n. sp. (2 ${ }^{\mathrm{a}}$ Nota prévia). Brazil-Med 1914, 28, pp. 183. 